Bangladesh J. Plant Taxon. 13(1): 21-28, 2006 (June)

\title{
THE GENUS MICROLEPIA PRESL (DENNSTAEDTIACEAE) FROM BANGLADESH
}

\author{
Momtaz Mahal Mirza \\ Bangladesh National Herbariumm Chiriakhana Road, Mirpur-1, \\ Dhaka-1216, Bangladesh
}

Key words : Microlepia, Dennstidiaceae, Pteridophyte, New record, Bangladesh

\begin{abstract}
The paper deals with the genus Microlepia Presl of the family Dennstaedtiaceae, which includes 4 species, namely, M. hookeriana (Wall. ex Hook.) Presl, M. strigosa (Thunb.) Presl, M. speluncae (L.) Moore and M. hancei Prantl from Bangladesh, of which last one is a new record.
\end{abstract}

\section{Introduction}

The genus Microlepia Presl of the family Dennsteadtiaceae is a tropical genus with about 46 terrestrial species, most of which are Asiatic, extending as far as New Zealand and Madagascar in the south and Japan in the North, (Nayar and Kaur1963). In Bangladesh the family is represented by the genus Microlepia Presl with four species, namely, M. hookeriana (Wall. ex Hook.) Presl, M. strigosa (Thunb.) Presl, M. speluncae (L.) Moore and M. hancei Prantl, of which the last one is a new record for Bangladesh. Prain (1903) recorded only two species, Davallia strigosa Sw. (M. strigosa), and D. speluncae Bak. (M. speluncae) from Chittagong. Dixit (1984) recorded M. speluncae from Bangladesh. Later on Mirza and Rahman (1977) recorded, M. hookeriana, M. strigosa, and M. speluncae, from Bangladesh in a checklist. Here full description of each species with diagrams are provided.

The present work was based on the material deposited at Bangladesh National Herbarium (DACB), Kew Herbarium (K) and also Central National Herbarium (CAL), for taxonomic study of the species, and to evaluate the number of members of the family in Bangladesh.

The taxonomic description with keys to the species, illustrations, specimens examined, distribution, short notes and proposal for present conservation measures are given below.

Microlepia Presl, Tent. Pterid.: 124 (1836).

Lectotype : Microlepia polypodiodes (Sw.) Presl (= Dicksonia polypodiodes Sw.)

Terrestrial, rhizome short or long creeping, profusely branched and covered with deciduous hairs. Fronds generally large, simple, pinnate or variously compound. Stipe continuous with the rhizome, long, cylindrical usually covered with short hairs; rachis shallowly grooved, costae of pinnules slightly grooved, ultimate pinnules obliquely 
incised, usually hairy; texture herbaceous, thin. Veins free. Sori intermarginal, terminal base, receptacle short, annulus of 16-20 cells, straight and interrupted, succession of sporangia gradate or more or less mixed; spores tetrahedral, smooth or tuberculate.

Microlepia is a genus of worldwide distribution, but mainly Asiatic. They are usually grown in restricted to deeply shaded, moist localities, forming small colonies in wellprotected areas in the plains and hills of low elevations.

\section{Key to the species}

1. Fronds simple pinnate to bi-pinnatified

- $\quad$ Fronds tripinnate- quadripinnate

2. Lamina simple pinnate, sori close to the margin

M. hookeriana

Lamina bipinnate, sori submarginal

M. strigosa

3. Fronds strong, primary and secondary rachis shallow, lamina profusely hairy all over

- $\quad$ Fronds lax, dorsal groove on stipe, primary and secondary rachis deep, foliar hair restricted to veins

M. speluncae

M. hancei

1. Microlepia hancei Prantl Arb. Bot. Gart, Breslau $1: 35$ (1892).; Nayar and Kaur, Bull. Nat. Bot.

Gard. 79: (1963). Microlepia speluncae (L.) Moore var. hancei (Prantl). Chr. Ind. Fil. : 426 (1906).

Davallia polypodiodes Benth. Fl. Hook. : 461 (1861).

(Plate 1)

Rhizome widely creeping, and densely covered with slender pale brown uniseriate hairs. Stipe densely hairy, about .5- $1.5 \mathrm{~cm}$. thick at the base 40-60 cm. long. Fronds tripinnate- quadripinnatified. Lamina loosely placed, deltoid, about 50-90 cm. long 30-40 $\mathrm{cm}$. broad. Rachis densely hairy and prominently grooved on the dorsal surface. The larger primary pinnae about 25-40 cm. long, and 6-12 cm. broad, oblong-lanceolate and loosely placed, the lower ones $5-8 \mathrm{~cm}$. apart, with rachis straight and prominent dorsal median grooves. The lower secondary pinna on the acroscopic side is larger than the basiscopic one. The secondary pinnae $5-10 \mathrm{~cm}$. long, 2.0-2.5 cm. broad, more or less loosely placed, pinnate except at the acuminate apex where it is pinnately lobed into small rhomboidal to sufalcate lobes. Rachis of the secondary pinnae straight grooved on the upper surface, hairy throughout. Tertiary pinnae about 1.5-2.0 cm. long 5-.8 cm. broad with cuneate base, with blunt round apex, lobes rhomboidal in shape. Texture pellucid-herbaceous, hairs absent on the lamina between the veins. Veins not prominent. Indusia small glabrous. Sori submarginal and confined to the basal acroscopic veinlet in the lower lobes, 1-3 sori on either margin of the large basal lobes. Chromosome number $\mathrm{n}=43$ (Kramer 1990).

Specimen examined : Panchagarh : Tetulia, (17.7. 2005), Momtaz Mahal Mirza, Mm 661 (DACB). Thakurgoan : Sadar thana, (17.8.98), M.S. Khan, K10080 (DACB).

Distribution : India, China and Hong Kong. 


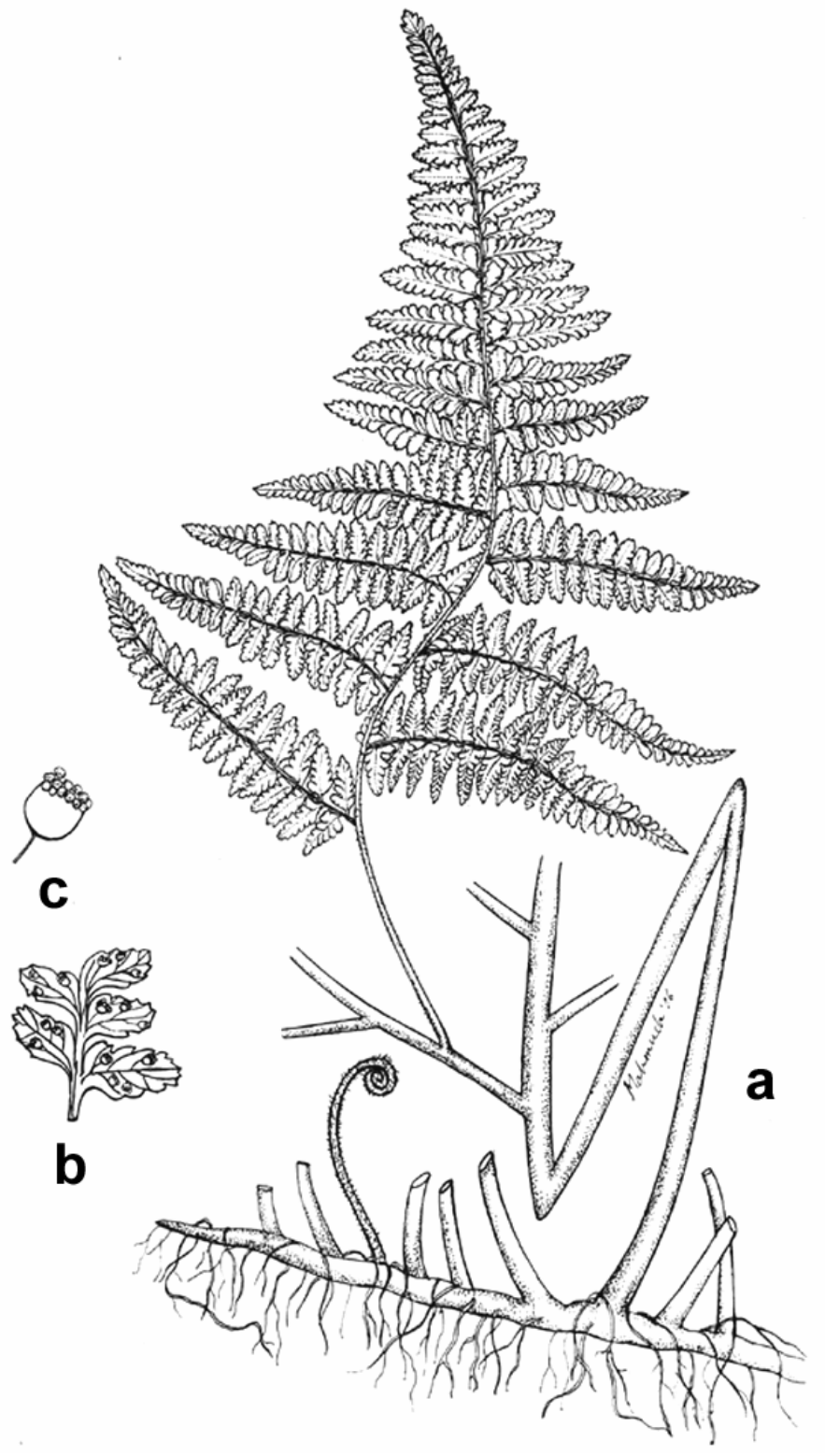

Plate 1. Microlepia hancei Prantl. a. habit $(\times 0.16)$; b. fertile pinnae showing arrangement of the sori $(\times 1.33)$; c. cup shaped sori $(\times 3.33)$.

M. hancei is repoted for the first time from Panchagarh and Thakurgoan, Bangladesh. It is a terrestrial fern growing by the road side about $90 \mathrm{~cm}$. long, with very strong wild smell. It is fairly common in the above areas, where the young fronds are eaten as vegetables. 
2. Microlepia hookeriana (Wall. ex Hook.) Presl, Epim. Bot.: 95 (1851). Davallia hookeriana Wall. ex Hook., Sp. Fil. 1: 172 (1846).

(Plate 2)

Stipe more than $90 \mathrm{~cm}$ long, pubescent, rachis hirsute. Fronds simple pinnate, lanceolate. Pinnules 25-30 pairs, sessile, alternate, acroscopic base with large auricled, basioscopic base, sometime shortly auricled, apex shortly acuminate, margin bi-crenulate.

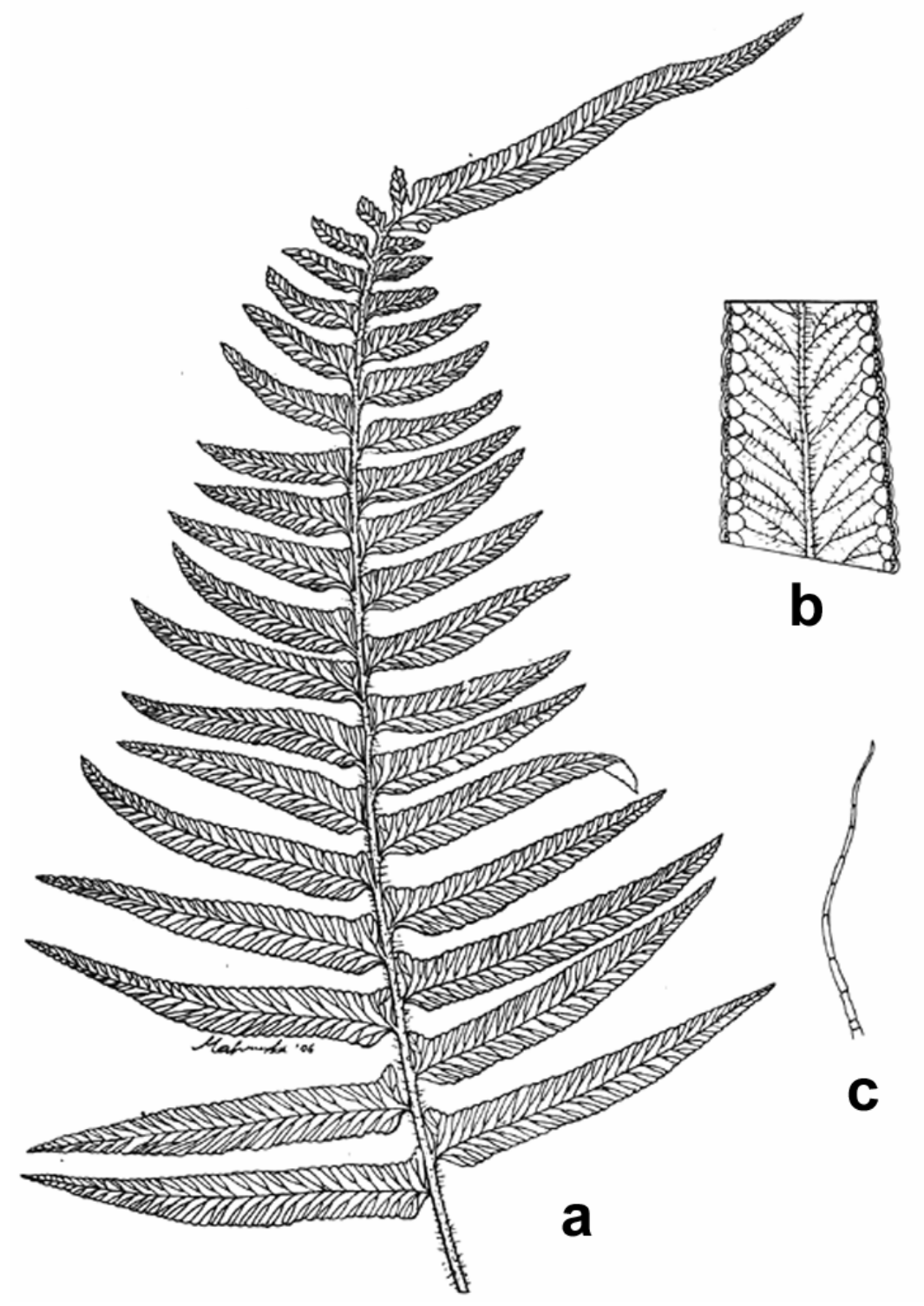

Plate 2. Microlepia hookeriana (Wall ex Hook.) Presl. a. part of pinnae $(\times 0.67)$; b. fertile pinnae showing arrangement of the sori and venation $(\times 6.67)$; c. dermal hair $(\times 10)$. 
Veins parallel, hairy on the costa and veins beneath, dichotomously branched. Sori borne inter- marginally on the undersurface of the pinnae, at the apices of some lateral veinlets, small, round and protected by a half cup-shaped indusium which is attached at the base and the sides open towards the leaf margin. Spores trilete, with a triangular amb and are devoid of perine. Chromosome number is $n=43$ (Kramer, 1990).

Specimens examined : Sylhet : Wallich $s . n$. [Type (K)].

Distribution : China, India, Malay Islands, Nepal, and Taiwan.

$M$. hookeriana is rare in Bangladesh. There was only one collection made by Wallich from Sylhet which is a type specimen. Intensive search should be made to relocate the species, type locality, neighbouring areas, and if the plants are located, then attempt should be made to conserve it through in-situ and ex-situ methods.

3 . Microlepia speluncae (L.) Moore Ind. Fil.: 93 (1857). Polypodium speluncae L., Sp. Pl. 2: 1093 (1753).

(Plate 3).

Rhizome widely creeping, branched, densely clothed by pale brown, multicellular, uniseriate hairs all over. Stipes strong $35-50 \mathrm{~cm}$ long, green or pulplish, hairy. Fronds upto 90-150 cm. long, 21-40 cm. broad. Lamina ovate to deltoid, deeply tripinnatified, basal pinnae somewhat reduced; rachis densely hairy. Pinnae $14-28 \mathrm{~cm}$. long, pinnules $2.5 \times 1.5 \mathrm{~cm}$ narrowly deltoid, acuminate, apex blunty rounded, edges lobed or not. Sori near the base of the sinuses between the lobes, 1-5 to the entire segments, more copious on the lobes, segments varying in size; involucre half cup-shaped, hispid or rarely glabrous, sporangia many, generally spreading to hide the indusium completely. Spores trilete, densely but often faintly granulose, perine absent. Chromosome number $n=43$ (Kramer 1990).

Specimens examined : Chittagong: Rangapani forest, (30.10.1978), Huq, Rahman, and Mia, H.4017 (DACB); Chittagong (1880) Gamble 7820 (K); Chittagong, (5.1.1857), Hooker and Thomson 308 (K). Dhaka: Bikrampur, Roshernen(4.8.1871), Clarke 14125A (K). Dinajpur: Dinajpur, (20.10.1976), Huq, Rahman, and Mia, H.2911 (DACB). Habiganj: Rema- Kalenga Wild Life Sanctuary, Debra bari, (2.4.1994), Khan, Islam, Zashim, K.9772 (DACB). Panchagarh: Boro awoliar mazar (18.7.2005), Momtaz Mahal Mirza Mm. 674 (DACB). Rangpur: Chilahati, (!7.10.1976), Huq, Rahman, and Mia, H .2738 (DACB). Sylhet: On the way to Jaintea (5.4.1988), Momtaz, Huq, Rahman and Hosne ara, Mm.08 (DACB); Sylhet, (4.12.1850), Hooker and Thomson 308E (K); $60 \mathrm{~m}$ away from Sylhet (17.6.1886), Clarke 42718D (K). Thakurgaon: Baliadangi, (4.8.1998), Khan , Harun, Nasir, Zashim K.9981 (DACB).

Distribution : India (Himalayas, South India), Sri Lanka, Malay Peninsula, Malayan Islands, Polynesia and Tropical America. 
M. speluncae grows all over Bangladesh and is fairly common. Young fronds are plucked from the wild and cooked as vegetable. It is nutritious and tasty. Juice of the frond is given to the patients suffering from fever for long time (Panchagarh).

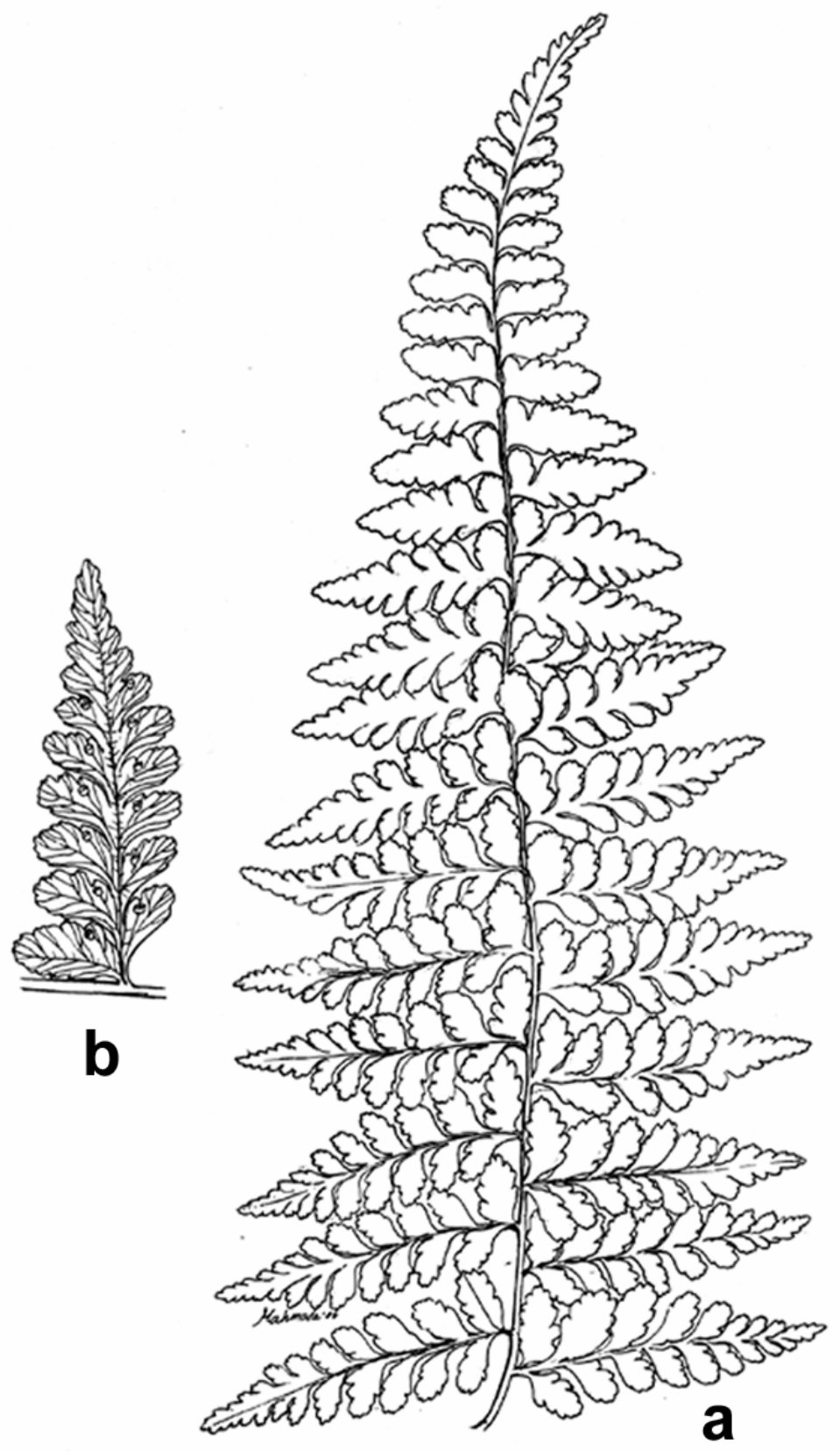

Plate 3. Microlepia speluncae (L.) Moore. a. a part of pinnae $(\times 0.75)$; b. fertile pinnae showing arrangement of the sori, venation and hairs $(\times 10)$. 
4. Microlepia strigosa (Thunb.) Presl, Epim Bot.: 95 (1849). Trichomanes strigosum Thunb., Fl. Jap.: 339 (1784).

(Plate 4)

Rhizome long creeping, branched, up to $0.5 \mathrm{~cm}$. thick, densely covered with dark brown, multicellular hairs all over. Stipes about $2.5-5 \mathrm{~cm}$. apart, elongated, hairy towards the base, with shorter hairs towards the apex. Fronds long, lanceolate, bipinnate, rachis

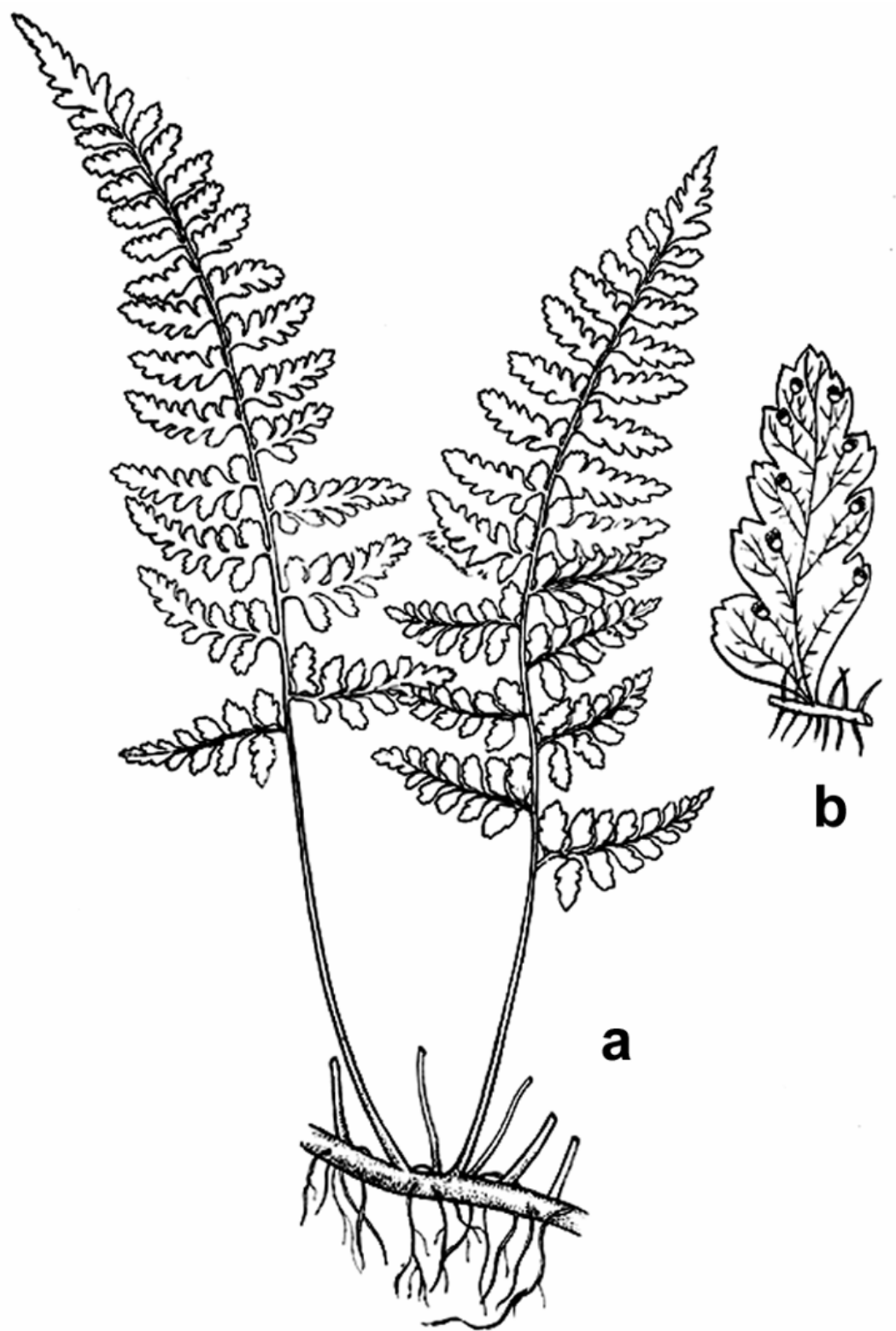

Plate 4. Microlepia strigosa (Thunb.) Presl. a. habit $(\times 0.16)$; b. fertile pinnae showing arrangement of the sori $(\times 3.4)$. 
and veins pubescent, hispid. Lamina about $20-40 \mathrm{~cm}$. long, primary pinnae petiolate, lanceolate acuminate, about 10 pairs, ascending, lower 1-2 pairs slightly reduced, subopposite, others alternate, apex acute or subacute, or rounded, margin lobed, $1 / 4-1 / 2$ way to the costa mostly petiolate, submediate-ovate, obtuse pinnatifid, chiefly on the upper edge, lower lobes obovate, angulate dentate. Veins slightly distinct above, clearly distinct below, furnished with a few long scattered hairs both above and beneath. Sori sub marginal at the end of acroscopic veinlet, covered by broadly cup-shaped indusia; indusia crenate or fimbriate when mature, bearing few hairs. Chromosome number $n=43$ (Kramer 1990).

Specimens examined : Cox's Bazar: Teknaf (3.3.1989), Ali, coll. s.n. (DACB); (March, 1880), Gamble 7816(K). Panchgarh: Tetulia (17.7.2005), Momtaz Mahal Mirza, Mm. 656 (DACB). Sylhet: Satchari (17.5.2005), Momtaz Mahal Mirza, Mm. 526b (DACB); Kalenga, (16.5.2005), Momtaz Mahal Mirza, Mm. 504 (DACB).

Distribution : North India, Japan, Sri Lanka and Polynesia.

$M$. strigosa is not common like M. speluncae, but grows well and forms thickets in open places by the road side, village jungles and forest floor. The taxon is being destroyed by the grazing animals as well as by the habitat destruction. Therefore, both insitu and ex- situ conservation measures should be undertaken.

\section{Acknowledgement}

The author is grateful to National Professor A.K.M. Nurul Islam, Department of Botany, University of Dhaka for his help and cooperation during the preparation of the manuscript.

\section{References}

Dixit, R. D. 1984. A census of the Indian Pteridophytes. Delhi, Botanical Survey of India. pp. 98- 102.

Kramer, K.U.1990. In: Kramer, K.U. and Green, P.S. (ed's). The families and genera of vascular plants. Pteridophytes, Gymnosperms. Springer-Verlag. New York. pp. 81-94.

Mirza, M. M. and Rahman M. M. 1997. An annotated check list of ferns and fern-allies of Bangladesh. Bangladesh J. Plant Taxon. 4(2): 47- 69.

Nayar, B.K. and Kaur, S. 1963. Microlepia Presl. Bulletin of the National Botanic Gardens. Lucknow, 79: 125.

Prain, D. 1903. Bengal Plants. (Indian Reprint 1981). Bishen Singh Mahendra Pal Singh, Dehra Dun. pp.1237-1270. 